\title{
Safety of Polysorbate 80 in the Oncology Setting
}

\author{
Lee S. Schwartzberg (D) R Rudolph M. Navari
}

Received: March 16, 2018 / Published online: May 23, 2018

(C) The Author(s) 2018

\begin{abstract}
Polysorbate 80 is a synthetic nonionic surfactant used as an excipient in drug formulation. Various products formulated with polysorbate 80 are used in the oncology setting for chemotherapy, supportive care, or prevention, including docetaxel, epoetin/darbepoetin, and fosaprepitant. However, polysorbate 80, like some other surfactants, is not an inert compound and has been implicated in a number of systemic and injection- and infusion-site adverse events (ISAEs). The current formulation of intravenous fosaprepitant has been associated with an increased risk of hypersensitivity systemic reactions (HSRs). Factors that have been associated with an increased risk of fosaprepitant-related ISAEs include the site of administration (peripheral vs. central venous), coadministration of anthracycline-based chemotherapy, number of chemotherapy cycles
\end{abstract}

Enhanced digital content To view enhanced digital content for this article go to https://doi.org/10.6084/ m9.figshare.6171023.

L. S. Schwartzberg $(\bowtie)$

Division of Hematology/Oncology, Department of Medicine, University of Tennessee Health Science Center and West Cancer Center, Memphis, TN, USA e-mail: lschwartzberg@westclinic.com

R. M. Navari

Division of Hematology and Oncology, University of Alabama Birmingham, Birmingham, AL, USA or fosaprepitant doses, and concentration of fosaprepitant administered. Recently, two polysorbate 80 -free agents have been approved: intravenous rolapitant, which is a neurokinin 1 (NK-1) receptor antagonist formulated with the synthetic surfactant polyoxyl 15 hydroxystearate, and intravenous HTX-019, which is a novel NK-1 receptor antagonist free of synthetic surfactants. Alternative formulations will obviate the polysorbate 80-associated ISAEs and HSRs and should improve overall management of chemotherapy-induced nausea and vomiting.

Funding: Heron Therapeutics, Inc.

Keywords: Fosaprepitant;

Injection-site adverse events; Oncology; Polysorbate 80; Safety

\section{INTRODUCTION}

Polysorbate 80 , also known as Tween 80 , is a synthetic nonionic surfactant commonly used in food, cosmetics, and drug formulations as a solubilizer, stabilizer, or emulsifier [1-3]. Polysorbate 20 and 60 (Tween 20 and 60) are also included in this family of surfactants $[1,4]$. It has also been used to prevent protein adsorption and/or aggregation [2]. A wide range of pharmaceutical agents are available in formulations that contain polysorbate 80 , including amiodarone [5], vitamin K [6], etoposide [3], 
docetaxel [7], various vaccines [8], protein biotherapeutics [2], erythropoietin-stimulating agents [9, 10], and fosaprepitant [11]. Recent data have indicated that polysorbate 80 is a biologically and possibly pharmacologically active compound and consequently may alter the pharmacologic properties of the drug it is formulated with or may itself directly mediate adverse events [3, 12]. Consequently, polysorbate 80 has been implicated in some of the adverse reactions associated with drugs formulated with this vehicle.

This review covers the safety of polysorbate 80 in the oncology setting, focusing on polysorbate 80 -associated adverse events that may have occurred with the use of docetaxel, darbepoetin alfa, epoetin alfa, and fosaprepitant.

This article is based on previously conducted studies and does not involve any new studies of human or animal subjects performed by any of the authors.

\section{OVERVIEW OF POLYSORBATE 80}

\section{Chemistry of Polysorbate 80}

Polysorbate 80 is a synthetic surfactant composed of fatty acid esters of polyoxyethylene sorbitan [1,2]. The fatty acid composition is primarily oleic acid, but other fatty acids, such as palmitic or linoleic acid, may be included (Fig. 1). Therefore, polysorbate 80 is usually available as a chemically diverse mixture of different fatty acid esters with the oleic acid comprising $>58 \%$ of the mix [1]. However, the main component of polysorbate 80 is polyoxyethylene-20-sorbitan monooleate, structurally similar to polyethylene glycols. Polysorbate 80 has a molecular weight of 1309.7 Da and a density of $1.064 \mathrm{~g} / \mathrm{ml}$ [3].

Polysorbate 80 has both hydrophobic and hydrophilic moieties [1, 2]. The hydrophobic moieties drive an interaction with the air-water interface or a solid-water interface, such as that found in vials, syringes, and other glass and plastic containers [2]. The hydrophobic moieties of polysorbate 80 also result in the formation of micelles at concentrations above the critical micelle concentration of $0.01 \%$ (weight/ volume) in protein-free aqueous solution [3]. This formation of micelles may play a critical role in the mechanism of action of polysorbate 80. Enzyme-linked immunosorbent assays have shown that polysorbate 80 could activate the complement system, a multiprotein immune mechanism. Activating the complement system may lead to phagocytosis, stimulation, and recruitment of white blood cells, or perforation of plasma membranes, possibly leading to immunologic side effects such as acute hypersensitivity and systemic immune reactions [13]. This possibility has been tested in a zebrafish model, where oxidized fatty acid residues in polysorbate 80 samples caused anaphylactoid reactions at the highest tested concentrations [14]. Polysorbate 80 substituted for human serum albumin in an epoetin alfa preparation in Europe is thought to have played a role in the

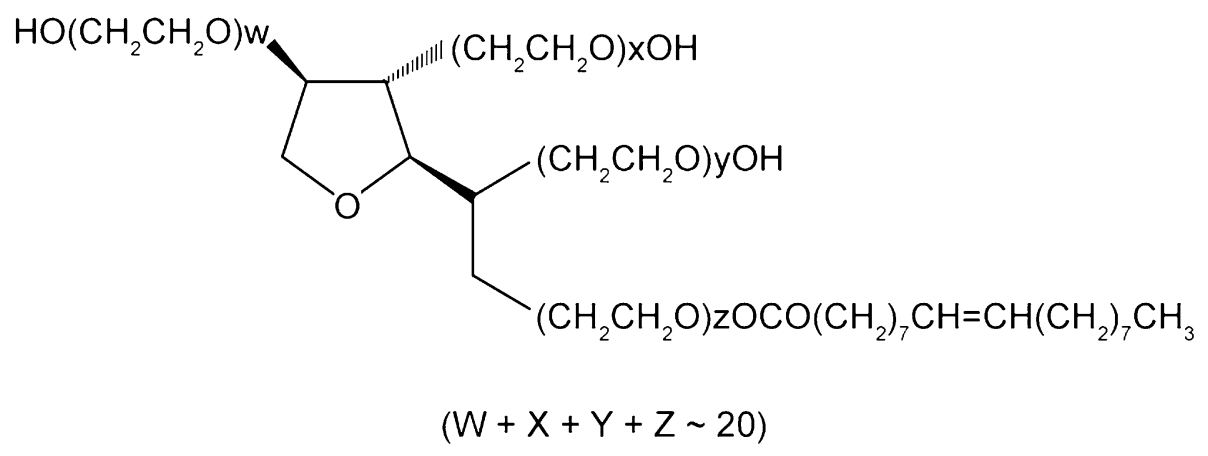

Fig. 1 Chemical structure of the primary constituents of polysorbate 80 (Republished from ten Tije et al. [3] with permission; copyright (C) 2003 Springer Nature, New York, NY, USA) 
development of neutralizing antibodies and pure red blood cell aplasia [15]. However, it is not yet known which specific parts of the chemical structure of polysorbate 80 are responsible for adverse events such as systemic and administration-site reactions.

Aqueous solutions of polysorbate 80 , as well as the undiluted liquid, undergo auto-oxidation over time, with changes being catalyzed by light, increased temperature, and copper sulfate [16]. Auto-oxidation leads to the formation of a variety of hydroperoxides, peroxides, and carbonyl compounds that may readily degrade proteins [16]. During the initial stages of propagation, the peroxide formation is usually faster than its decomposition; eventually, the rates of formation and decomposition equalize, and then decomposition occurs faster than formation [16]. Parameters such as surface tension and cloud point properties may be used to establish degradation in the hydrophilic chains [16].

\section{Pharmacokinetic Properties of Polysorbate 80}

In both animal [17] and clinical studies [18, 19], polysorbate 80 is rapidly removed from systemic circulation. The polysorbate 80 plasma concentration-time curve (AUC) in a patient administered an intravenous (IV) infusion of docetaxel $35 \mathrm{mg} / \mathrm{m}^{2}$ (polysorbate $80 \quad 1.75 \mathrm{~g}$ ) showed a polysorbate 80 peak concentration of $304 \mu \mathrm{g} / \mathrm{ml}$ [18]. The AUC for polysorbate 80 was $321.7 \mathrm{mg} \mathrm{h} / \mathrm{ml}$, with a short disposition half-life of $1.07 \mathrm{~h}$ and a total plasma clearance of 5.44 $\mathrm{l} / \mathrm{h}$. The volume of distribution of polysorbate 80 at steady state was similar to the total blood volume (4.16 l), suggesting that polysorbate 80 circulates as large micelles and does not significantly distribute outside the central compartment [18]. In vitro studies suggest that polysorbate 80 is metabolized by rapid carboxylesterase-mediated hydrolysis [17].

Polysorbate 80 may potentially have an effect on the distribution and elimination of some IV-administered drugs with which it has been formulated (Table 1) [20-25]. This effect may lead to increased systemic exposure and
Table 1 Pharmacokinetic effects of drugs formulated with polysorbate 80

\begin{tabular}{|c|c|}
\hline Drug & Effect of polysorbate 80 \\
\hline \multicolumn{2}{|l|}{ Preclinical studies } \\
\hline $\begin{array}{l}\text { Doxorubicin } \\
{[20]}\end{array}$ & Increased concentration in plasma \\
\hline $\begin{array}{l}\text { Methotrexate } \\
{[21]}\end{array}$ & $\begin{array}{l}\text { Increased uptake in brain } \\
\text { Increased absorption } \\
\text { Increased excretion into bile }\end{array}$ \\
\hline Etoposide [22] & $\begin{array}{l}\text { Increased AUC and decreased } \\
\text { elimination }\end{array}$ \\
\hline \multicolumn{2}{|l|}{ Clinical studies } \\
\hline $\begin{array}{l}\text { Doxorubicin } \\
{[23]}\end{array}$ & $\begin{array}{l}\text { Increased volume of distribution up to } \\
\text { 3-fold } \\
\text { Decreased AUC up to 2-fold } \\
\text { Increased clearance up to 2-fold }\end{array}$ \\
\hline Paclitaxel [24] & Increased concentration in brain \\
\hline Docetaxel [25] & Increased fraction unbound in plasma \\
\hline
\end{tabular}

$A U C$ area under the plasma concentration-time curve

decreased clearance of the drug [3]. For example, polysorbate 80 may influence the binding of docetaxel in a concentration-dependent manner [25]. A potential explanation of this effect may be that polysorbate 80 forms micellar complexes with proteins, so that the binding of docetaxel becomes saturated on single sites and the fraction of unbound drug increases $[3,25]$. An alternative explanation is that the metabolism of polysorbate 80 and the subsequent displacement of oleic acid-mediated proteinbinding sites may cause an increase in the fraction of unbound drug [3].

\section{Pharmacodynamic Properties of Polysorbate 80}

Polysorbate 80 has demonstrated several pharmacodynamic properties, including altering membrane fluidity and increasing membrane permeability [26]. An in vitro study indicated that polysorbate 80 potentiated the effect of antibiotics in resistant cell lines, which was 
thought to be due to the effect of polysorbate 80 on cell membrane permeability [27]. In vitro, polysorbate 80 increases the susceptibility of cells to oxidative stress [28]. In animal tumor models, it appears to have cytotoxic effects [3]. Cytotoxicity and antitumor activity associated with polysorbate 80 may be linked to the release of oleic acid, known to interfere with cell proliferation through the formation of peroxides [29-32].

In animal studies, polysorbate 80 has been associated with a profound and sustained decrease in blood pressure, which may be attributable to the negative inotropic properties of polysorbate 80 [33]. In clinical studies, amiodarone formulations devoid of polysorbate 80 and benzyl alcohol had a substantially reduced risk of hypotension [5].

\section{Polysorbate 80 and Adverse Events}

Polysorbate 80 has been associated with a number of adverse events. In food, small concentrations of undigested polysorbate 80 may enhance bacterial translocation across intestinal epithelia, a potential explanation for an observed increase in the incidence of Crohn's disease [34]. In drug formulations, polysorbate 80 has been implicated in a number of systemic reactions (e.g., hypersensitivity, nonallergic anaphylaxis, rash) and injection- and infusionsite adverse events (ISAEs; e.g., pain, erythema, thrombophlebitis) [3, 35-37]. Polysorbate 80 has also been implicated in cases of renal and liver toxicity [38-40].

\section{POLYSORBATE 80 IN THE ONCOLOGY SETTING}

Various chemotherapeutic, supportive care, and preventative agents used in the oncology setting utilize polysorbate 80 in their formulations, including docetaxel (Taxotere $^{\circledR}$, Sanofi-Aventis US LLC), the biologicals epoetin alfa $\left(\right.$ Epogen $^{\circledR}$, Amgen Inc.; Procrit ${ }^{\circledR}$, Amgen Inc.) and darbepoetin alfa (Aranesp ${ }^{\circledR}$, Amgen Inc.), and the antiemetic fosaprepitant IV (Emend ${ }^{\circledR}$ IV, Merck, Sharp \& Dohme). Certain adverse events (both systemic and ISAE) occur with these drugs, in which polysorbate 80 may be implicated. There are some challenges in evaluating the literature on this topic, as attribution of adverse events to polysorbate 80 is confounded by its administration with the pharmacologically active agent and by the heterogeneity of reporting of these adverse events in clinical trials. However, there is evidence to implicate polysorbate 80 in systemic and administration-site reactions.

\section{Docetaxel}

Docetaxel is a taxane that inhibits cell replication by stabilizing the microtubule cytoskeleton $[7,41]$. To solubilize this agent for clinical use, it has been formulated using polysorbate 80 . An injection concentrate $(20 \mathrm{mg} / \mathrm{ml})$ comprises $20 \mathrm{mg}$ of docetaxel in $1 \mathrm{ml}$ at a $50 / 50(\mathrm{~V} / \mathrm{V})$ ratio of polysorbate 80/dehydrated alcohol. Currently, docetaxel is indicated for the treatment of several cancers, including locally advanced or metastatic breast cancer, locally advanced or metastatic non-small cell lung cancer, hormone-refractory prostate cancer, gastric adenocarcinoma, and squamous cell carcinoma of the head and neck [7].

Docetaxel has been associated with a number of ISAEs and systemic reactions [7, 42, 43], including hypersensitivity $[3,7]$, fluid retention $[3,7]$, cutaneous reactions $[7,44]$, gastrointestinal adverse events [7], and peripheral neuropathy $[3,7]$. In clinical trials in patients with cancer, the incidence of ISAEs has been reported to be $3-4 \%$ [7].

The presence of polysorbate 80 in the IV formulation of docetaxel has been implicated in hypersensitivity systemic reactions (HSRs) that were observed in the early clinical studies $[3,45]$. In those studies, the incidence of HSRs ranged from $5 \%$ to $40 \%$, with most events being grade 2 in severity on the four-point scale of the National Cancer Institute common toxicity criteria [3]. Severe HSRs or, very rarely, fatal anaphylaxis have been reported in patients treated with docetaxel [7]. Polysorbate 80 and the oleic acid released by its metabolism have been implicated in the HSRs seen with docetaxel therapy [46]. Consequently, patients 
treated with the conventional formulation of docetaxel are premedicated with oral corticosteroids [7].

Developments in formulating docetaxel IV without polysorbate 80 include dendrimer (Dep) docetaxel $[47,48]$ and nanosomal docetaxel lipid suspension [22, 49]. In one study, the diminished potential for HSRs with the novel nanosomal docetaxel lipid suspension, compared with the conventional docetaxel formulation, reduced the requirement for premedication with corticosteroids [50].

\section{Supportive Care: Epoetin Alfa, Darbepoetin Alfa}

A number of subcutaneous and IV formulations of erythropoietin-stimulating agents (ESAs) contain polysorbate 80 . Darbepoetin alfa [10] is formulated with polysorbate 80 in the US. Outside the US, epoetin alfa $\left(\right.$ Eprex $^{\circledR}$, JanssenCilag Ltd; Erypo ${ }^{\circledR}$, Biocon Limited) [9] is formulated with polysorbate 80 , instead of human serum albumin, to avoid potential contamination by human immunodeficiency virus and Creutzfeldt-Jakob disease-causing prions [51]. These ESAs are indicated for the treatment of anemia and to reduce transfusion requirements in patients receiving myelosuppressive chemotherapy for cancer $[9,10,52]$. They act by stimulating erythropoiesis by the same mechanism as endogenous erythropoietin.

Adverse events associated with darbepoetin alfa in patients with cancer include abdominal pain, edema, and thrombovascular events [10]. HSRs, including cases of rash, anaphylactic reactions, and angioneurotic edema, have been reported with epoetin alfa [9]. In particular, the inclusion of polysorbate 80 in one epoetin alfa formulation has been associated with antibodymediated pure red cell aplasia (PRCA) in patients with chronic kidney disease [51].

\section{Supportive Care: Fosaprepitant (Emend IV)}

Aprepitant is a selective, high-affinity antagonist of human substance P/neurokinin 1 (NK-1) receptors that was first developed for oral administration [53, 54]. Aprepitant was approved in 2003 for the prevention of nausea and vomiting associated with emetogenic cancer chemotherapy [53]. Subsequently, an IV prodrug formulation (fosaprepitant; Emend IV) was approved in 2008; this formulation includes polysorbate 80 [11]. Because NK-1 antagonists target another important neurotransmitter/receptor involved in the emetogenic pathway, they complement 5-hydroxytryptamine type $3\left(5-\mathrm{HT}_{3}\right)$ receptor antagonists and enhance control of chemotherapy-induced nausea and vomiting $[55,56]$.

Most adverse events associated with fosaprepitant are mild to moderate in severity [57-64]. The most common adverse reactions ( $\geq 2 \%$ ) reported with fosaprepitant include fatigue, diarrhea, neutropenia, asthenia, anemia, peripheral neuropathy, leukopenia, dyspepsia, urinary tract infection, and pain in the extremities [11]. No fosaprepitant-associated deaths have been reported in prospective studies.

However, HSRs and ISAEs have been associated with fosaprepitant infusion, and in recent updates, labeling for fosaprepitant was changed to include a warning regarding its potential association with HSRs during or shortly after infusion, including anaphylaxis and anaphylactic shock. Symptoms such as flushing, erythema, dyspnea, hypotension, and syncope have also been reported. ISAEs such as thrombophlebitis, necrosis, and vasculitis were reported with anthracycline-based chemotherapy administration [11].

Several ISAEs have been associated with the use of fosaprepitant, including infusion-site pain, erythema, swelling, venous hardening or induration, and phlebitis or thrombophlebitis. Because of heterogeneity in reporting, wide ranges of ISAE incidences have been published (Table 2) [57-64]. For example, fosaprepitant, compared with aprepitant, was associated with an overall ISAE incidence of $2.2 \%$ vs. $0.4 \%$, respectively, of patients in a phase III trial [57]. Most of the ISAEs were mild to moderate, with $0.2 \%$ of fosaprepitant recipients reporting severe infusion-site pain and $0.8 \%$ reporting thrombophlebitis [57]. In another phase III trial, the incidence of ISAEs was $24 \%$ in those 
Table 2 Incidence of ISAEs in patients treated with fosaprepitant for the prevention of chemotherapy-induced nausea and vomiting associated with emetogenic chemotherapy

\begin{tabular}{|c|c|c|c|c|c|c|c|}
\hline \multirow[t]{2}{*}{ Study } & \multirow[t]{2}{*}{ Drug } & \multicolumn{6}{|c|}{ Incidence of ISAEs (\% patients) } \\
\hline & & Overall & Pain & Erythema & Swelling & $\begin{array}{l}\text { Venous hardening/ } \\
\text { induration }\end{array}$ & $\begin{array}{l}\text { Phlebitis/ } \\
\text { thrombo-phlebitis }\end{array}$ \\
\hline \multicolumn{8}{|c|}{ Prospective studies } \\
\hline \multirow[t]{2}{*}{$\begin{array}{l}\text { Grunberg } \\
\text { et al. [57] }\end{array}$} & $\begin{array}{l}\text { Fosaprepitant } \\
(n=1143)\end{array}$ & 2.2 & 1.4 & 0.5 & 0 & 0.2 & 0 \\
\hline & $\begin{array}{l}\text { Aprepitant } \\
\qquad(n=1169)\end{array}$ & 0.4 & 0.1 & 0.1 & 0.1 & 0.1 & 0.1 \\
\hline \multirow[t]{2}{*}{$\begin{array}{l}\text { Saito et al. } \\
{[58]}\end{array}$} & $\begin{array}{l}\text { Fosaprepitant } \\
\qquad(n=174)\end{array}$ & $23.6^{\mathrm{a}}$ & 15.5 & 5.2 & 3.4 & 0.6 & 2.3 \\
\hline & $\begin{array}{l}\text { Placebo } \\
\qquad(n=170)\end{array}$ & 12.4 & 6.5 & 5.3 & 2.9 & 0.6 & 2.4 \\
\hline \multirow[t]{2}{*}{$\begin{array}{l}\text { Weinstein } \\
\text { et al. [59] }\end{array}$} & $\begin{array}{l}\text { Fosaprepitant } \\
\qquad(n=504)\end{array}$ & NR & NR & NR & NR & NR & 0.6 \\
\hline & $\begin{array}{l}\text { Control } \\
\qquad(n=497)\end{array}$ & NR & NR & NR & NR & NR & 0 \\
\hline \multicolumn{8}{|c|}{ Retrospective studies } \\
\hline \multirow[t]{2}{*}{$\begin{array}{l}\text { Hegerova } \\
\text { et al. }[60]^{\mathrm{b}}\end{array}$} & $\begin{array}{l}\text { Fosaprepitant } \\
\qquad(n=99)^{c}\end{array}$ & 34 & 27 & 22 & 12 & 4 & 5 \\
\hline & $\begin{array}{l}\text { Fosaprepitant } \\
\quad(n=81)\end{array}$ & 8 & 0 & 0 & 3 & 0 & 3 \\
\hline \multirow[t]{2}{*}{$\begin{array}{l}\text { Tsuda et al. } \\
\text { [61] }\end{array}$} & $\begin{array}{l}\text { Fosaprepitant } \\
\qquad(n=38)^{\mathrm{c}}\end{array}$ & $96^{\mathrm{d}}$ & 92 & 40 & 32 & 29 & 16 \\
\hline & $\begin{array}{l}\text { Aprepitant } \\
\qquad(n=62)^{\mathrm{c}}\end{array}$ & 42 & 42 & 0 & 0 & 0 & 0 \\
\hline \multirow[t]{2}{*}{$\begin{array}{l}\text { Leal et al. } \\
{[60]^{\mathrm{b}}}\end{array}$} & $\begin{array}{l}\text { Fosaprepitant } \\
\qquad(n=98)^{\mathrm{c}}\end{array}$ & 35 & 27 & 22 & 12 & 4 & 5 \\
\hline & $\begin{array}{l}\text { Aprepitant } \\
\qquad(n=44)^{\mathrm{c}}\end{array}$ & 2 & 0 & 2 & 0 & 0 & 0 \\
\hline \multirow[t]{2}{*}{$\begin{array}{l}\text { Sato et al. } \\
{[63]}\end{array}$} & $\begin{array}{l}\text { Fosaprepitant } \\
\qquad(n=24)^{c}\end{array}$ & 67 & NR & NR & $\mathrm{NR}$ & NR & NR \\
\hline & $\begin{array}{l}\text { Control } \\
\qquad(n=32)^{\mathrm{c}}\end{array}$ & 16 & NR & NR & NR & NR & NR \\
\hline \multirow[t]{2}{*}{$\begin{array}{l}\text { Fujii et al. } \\
{[64]}\end{array}$} & $\begin{array}{l}\text { Fosaprepitant } \\
\qquad(n=120)^{\mathrm{e}}\end{array}$ & $42^{\mathrm{d}}$ & NR & NR & NR & 21 & NR \\
\hline & $\begin{array}{l}\text { Aprepitant } \\
\qquad(n=147)\end{array}$ & 11 & NR & NR & NR & 1.4 & NR \\
\hline
\end{tabular}


Table 2 continued

\begin{tabular}{|c|c|c|c|c|c|c|c|}
\hline \multirow[t]{2}{*}{$\overline{\text { Study }}$} & \multirow[t]{2}{*}{ Drug } & \multicolumn{6}{|c|}{ Incidence of ISAEs (\% patients) } \\
\hline & & Overall & Pain & Erythema & Swelling & $\begin{array}{l}\text { Venous hardening/ } \\
\text { induration }\end{array}$ & $\begin{array}{l}\text { Phlebitis/ } \\
\text { thrombo-phlebitis }\end{array}$ \\
\hline $\begin{array}{l}\text { Boccia et al. } \\
{[65]}\end{array}$ & $\begin{array}{l}\text { Fosaprepitant } \\
\qquad(n=127)^{\mathrm{f}}\end{array}$ & 28 & 19 & 19 & 14 & 3 & 0.8 \\
\hline $\begin{array}{l}\text { ISAEs injectior } \\
\mathrm{a} p<0.001 \mathrm{vs} \\
\mathrm{b} \text { These studie } \\
\mathrm{c} \text { Patients trea } \\
\mathrm{d} p<0.001 \mathrm{vs} \\
{ }_{\mathrm{e}} \text { All patients } \\
\mathrm{f} \text { Data corresp }\end{array}$ & $\begin{array}{l}\text { and infusion-si } \\
\text { placebo } \\
\text { have patients th } \\
\text { d with anthracy } \\
\text { aprepitant } \\
\text { cluding those tr }\end{array}$ & $\begin{array}{l}\text { dverse ever } \\
\text { ad periph } \\
\text { e chemoth } \\
\text { d with an } \\
\text { ISAEs in }\end{array}$ & $\begin{array}{l}\text { nts, } N R \\
\text { eral an } \\
\text { erapy } \\
\text { thracyc } \\
\text { cycle } 1\end{array}$ & not reporte & $\begin{array}{l}\text { d } \\
\text { ous access }\end{array}$ & & \\
\hline
\end{tabular}

treated with fosaprepitant vs. $12 \%$ in those who did not receive fosaprepitant $(p<0.01)$; no severe ISAEs were reported in this trial [58].

Retrospective trials, compared with prospective trials, reported even higher incidences of ISAEs with fosaprepitant (Table 2) [60-64]. The reported incidence of ISAEs ranged from $28 \%$ to $96 \%$ with fosaprepitant, with pain being the most frequently reported ISAE. The reasons proposed for the higher incidence of ISAEs in the retrospective trials, compared with the prospective trials, include the increased number of fosaprepitant injections associated with additional rounds of chemotherapy [60, 61, 63], increased concentration of fosaprepitant used in each dose [63], increased speed of delivery of each dose [63], and use of peripheral venous access rather than central venous access [60-64]. Interestingly, changing the administration route of fosaprepitant from peripheral injection to central venous injection reduced the risk of developing ISAEs [61-63].

The use of anthracycline, compared with non-anthracycline, chemotherapy regimens also appears to be implicated in the increased incidence of ISAEs; patients receiving anthracycline-based chemotherapy have higher ISAE incidences than those receiving platinum-based chemotherapy [60-64]. In one retrospective trial, in which $42 \%$ of fosaprepitant recipients experienced ISAEs [64], those ISAEs appeared to be confined to patients treated with an anthracycline-based chemotherapy regimen [odds ratio (OR) 12.95; 95\% CI 5.74-29.20; $p<0.001]$ and were not associated with a cisplatin-based chemotherapy regimen (OR 0.78; 95\% CI $0.20-3.05$; $p=0.717$ ). Similarly, another retrospective study reported fosaprepitant-associated ISAE incidences of $34 \%$ in anthracycline plus cyclophosphamide-treated patients compared with $8 \%$ in platinum-treated patients [60]. A recent retrospective review of ISAEs and HSRs associated with fosaprepitant in patients receiving anthracycline plus cyclophosphamide-based chemotherapy via peripheral IV line identified ISAEs and/or HSRs in $28 \%$ of patient charts reviewed [65].

The mechanism of vascular damage associated with fosaprepitant has not been precisely determined, but polysorbate 80 may be implicated. Polysorbate 80 has been associated with increased membrane permeability [26], and its combination with anthracyclines, which are also associated with an increase in vascular damage [66], may compound the effect [64]. Consequently, fosaprepitant injections through veins already damaged by anthracycline, or vice versa, may result in a greater frequency of ISAEs or skin induration [64].

\section{Changes in Practice at Specific Institutions}

Following the inclusion of fosaprepitant in the Mayo Clinic (Rochester, MN, USA) practice guidelines for highly emetogenic chemotherapy in January 2011, chemotherapy nurses began to 
(a)

Mayo Clinic

Fosaprepitant noninferiority to aprepitant $\mathrm{PO}$ on days 1-3 with HEC

Fosaprepitant included in

2011 Mayo Clinic practice guidelines for HEC (Jan 2011)

Nurses noticed more frequent ISAEs with fosaprepitant, particularly with $A C$

Retrospective EMR review of $A C$ patients revealed higher incidence of ISAEs with

\section{4} fosaprepitant vs. aprepitant

(b)

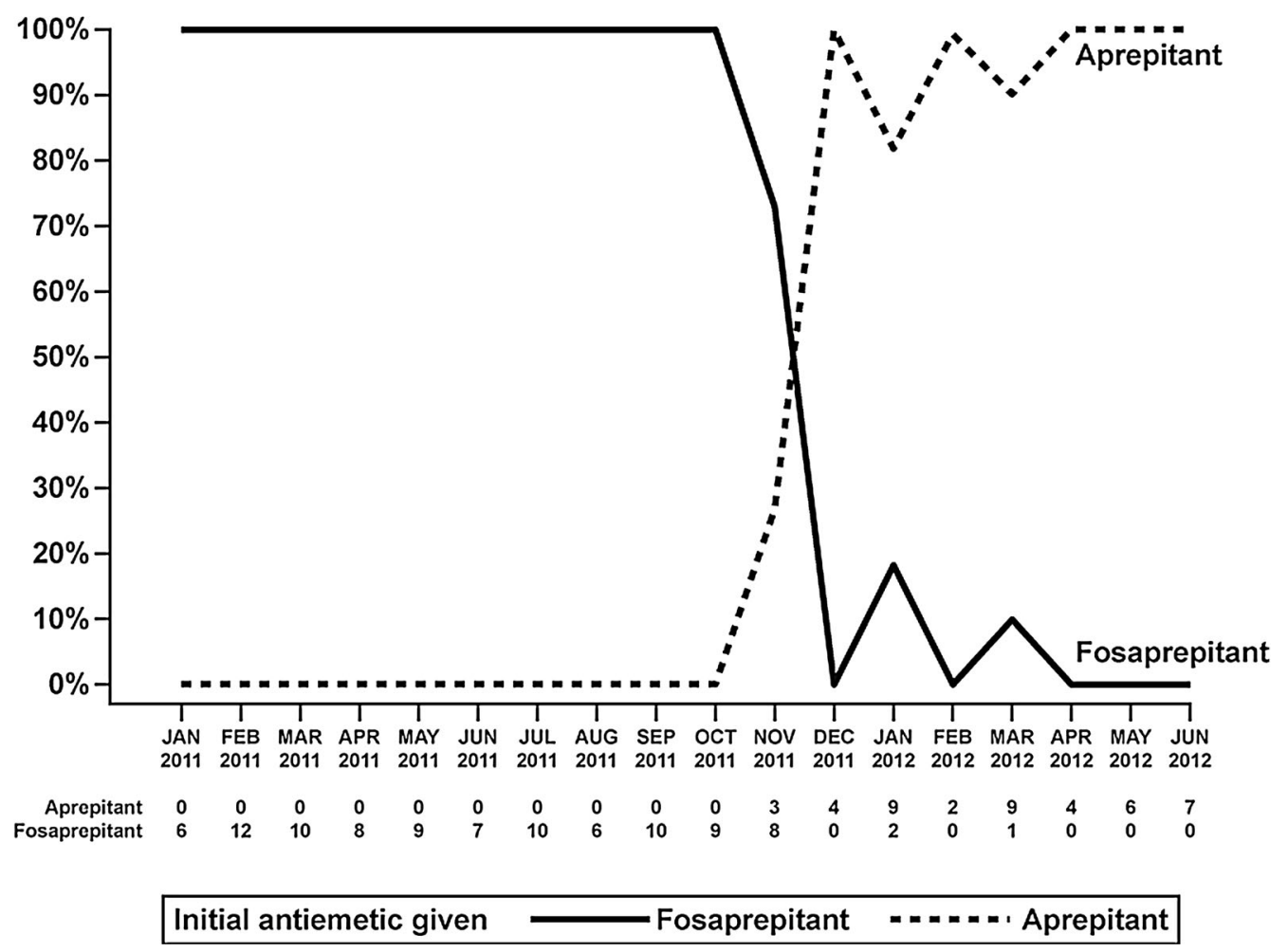


4Fig. 2 a Fosaprepitant center experience and changes in practice $[57,60,62]$. b Fosaprepitant and aprepitant administration rates at the Mayo Clinic reflecting changes in practice guidelines (b republished from Leal et al. [62] with permission; copyright (C) 2014 Springer-Verlag, Berlin, Germany). $A C$ anthracycline, EMR, electronic medical records, $H E C$ highly emetogenic chemotherapy, ISAEs injection- and infusion-site adverse events, $P O$ oral

notice more frequent ISAEs, particularly in patients receiving anthracycline regimens (Fig. 2a) [60]. A retrospective electronic medical records review of anthracycline-treated patients revealed a higher ISAE incidence with fosaprepitant vs. oral aprepitant (35\% vs. 2\%) [62]. Consequently, in 2015, the Mayo Clinic guidelines were changed back to recommend the use of oral aprepitant in patients receiving anthracycline-based regimens, with oral aprepitant becoming routinely used from that time forward (Fig. 2b).

A retrospective study of patient medical records was also conducted at the James Cancer Center (Columbus, OH, USA) [67], including patients who received fosaprepitant infusion via a peripheral line. The study included 150 patients who received 333 doses of fosaprepitant and a median of 2 fosaprepitant doses (range 1-7). ISAEs were reported in $15 \%$ of patients, with 50 reactions occurring in 43 unique patients. These ISAEs were grade 2 or less in severity and resolved within a few minutes to a few hours in most patients, although in $24 \%$ of patients ISAEs had a median duration of 14 days. Multivariate analyses per event identified increased age, location of the IV line (hand vs. forearm or antecubital fossa), and IV infusion rate $<100 \mathrm{ml} / \mathrm{h}$ as risk factors for ISAEs. Management strategies that had been used to treat these ISAEs included placement of new IV lines and warming the affected area for 15-20 min at least four times each day for the first $24-48 \mathrm{~h}$. Management strategies that were used to prevent future ISAEs included switching to oral aprepitant, switching to a different antiemetic regimen, prolonging the duration of fosaprepitant infusion, diluting fosaprepitant to $0.6 \mathrm{mg} / \mathrm{ml}$ for the next infusion, and placement of implanted ports. Because of the high incidence of ISAEs identified, the distress caused to patients, and the dissatisfaction with this issue reported by nursing staff, this institution changed its antiemetic protocol. Fosaprepitant was diluted in $250 \mathrm{ml}$ rather than $150 \mathrm{ml}$ of $0.9 \%$ sodium chloride base solution and was administered over $30 \mathrm{~min}$ rather than $20 \mathrm{~min}$ for all patients. Physicians were encouraged to use oral aprepitant or a different antiemetic regimen for patients who were to receive fosaprepitant via a peripheral line or who had experienced ISAEs with previous fosaprepitant infusion [67].

\section{FUTURE DIRECTIONS}

Polysorbate 80 is not a physiologically inert compound and may account for the increased risk of systemic adverse events and ISAEs associated with its use in drug formulations [3, 12]. Safety issues associated with polysorbate 80 have led to formulation changes for docetaxel within the oncology setting [22, 47-49].

In particular, fosaprepitant, which includes polysorbate 80 in its formulation, has been associated with an increased risk of HSRs and other systemic reactions including anaphylaxis; most recently, anaphylactic shock has been added per the 2017 label update. The update also includes symptoms such as hypotension and syncope [11], as well as increased ISAEs, compared with oral aprepitant. Factors that have been linked to the increased risk of fosaprepitant ISAEs include the site of administration (peripheral vs. central venous), coadministration of anthracycline-based chemotherapy, number of chemotherapy cycles or fosaprepitant doses, and concentration of the fosaprepitant administered.

There is a need for an IV formulation of an NK-1 receptor antagonist that does not use polysorbate 80 as a vehicle and that has a lower risk of HSRs and ISAEs. HTX-019 (Cinvanti ${ }^{\circledR}$, Heron Therapeutics) is a novel formulation of the NK-1 receptor antagonist aprepitant, which is free of polysorbate 80 and other synthetic surfactants. HTX-019 was approved in November 2017 [68] for use in combination with other antiemetic agents to prevent chemotherapy-induced acute and delayed nausea and vomiting 
associated with initial and repeat courses of highly emetogenic cancer chemotherapy, including high-dose cisplatin, and for nausea and vomiting associated with initial and repeat courses of moderately emetogenic cancer chemotherapy in adults. HTX-019 is bioequivalent to fosaprepitant and has a lower incidence of ISAEs, especially in the first hour following infusion [69]. An IV formulation of another NK1 receptor antagonist, rolapitant, was approved in November 2017 for use in combination with other antiemetics for the prevention of delayed chemotherapy-induced nausea and vomiting in adults. This IV formulation of rolapitant does not contain polysorbate 80; however, it does contain another synthetic surfactant, polyoxyl 15 hydroxystearate, for which limited clinical safety data are available [70-72]. Following approval of the rolapitant IV formulation, a US Food and Drug Administration MedWatch safety alert was issued on 16 January 2018 to health care providers, warning against HSRs including anaphylaxis and anaphylactic shock, which may occur during or following administration of rolapitant IV. Further, the alert recommended avoiding administration of the drug if the patient was hypersensitive to any ingredients in the drug formulation [73]. Subsequent to this warning about HSRs, the manufacturer issued a press release on 27 February 2018, announcing suspension of rolapitant IV distribution [74].

\section{CONCLUSION}

Polysorbate 80 is a nonionic surfactant commonly used as an excipient in drug formulations. Various agents used in the oncologic setting, such as docetaxel, epoetin/darbepoetin, and fosaprepitant, are formulated with polysorbate 80 . Polysorbate 80 appears to be a pharmacologically active compound and has been implicated in a number of systemic adverse events and ISAEs. The current formulation of fosaprepitant has been associated with an increased risk of HSRs such as anaphylaxis and anaphylactic shock, as well as increased ISAEs, compared with oral aprepitant. Factors that have been associated with an increased risk of fosaprepitant ISAEs include the site of administration (peripheral vs. central venous), coadministration of anthracycline-based chemotherapy, number of chemotherapy cycles of fosaprepitant doses, and concentration of the fosaprepitant administered. The recent approvals of HTX-019, a novel IV formulation of the NK-1 receptor antagonist aprepitant that is free of polysorbate 80 and other synthetic surfactants, provides a new and effective therapeutic option for the prevention of chemotherapy-induced nausea and vomiting with a reduced risk of HSRs and ISAEs.

\section{ACKNOWLEDGEMENTS}

Funding. Article processing charges, open access fees, and medical writing funded by Heron Therapeutics, Inc.

Medical Writing, Editorial, and Other Assistance. Medical writing assistance was provided by Yvonne Yarker, PhD, and Nirzari Parikh, PhD, of SciStrategy Communications (Conshohocken, PA) and funded by Heron Therapeutics, Inc.

Authorship. All authors meet the International Committee of Medical Journal Editors (ICMJE) criteria for authorship for this manuscript, take responsibility for the integrity of the work as a whole, and have given final approval to the version to be published.

Disclosures. Lee S. Schwartzberg has acted in a consultant/advisory role for Eisai, Helsinn, Merck, and Tesaro, received research funding from Helsinn, and served as a member of a speakers bureau or advisory committee for Helsinn and Merck. Rudolph M. Navari has acted in a consultant/advisory role for Heron Therapeutics, Inc.

Compliance with Ethics Guidelines. This article is based on previously conducted studies, and does not involve any new studies of human or animal subjects performed by any of the authors. 
Data Availability. Data sharing is not applicable to this article as no data sets were generated or analyzed during the current study.

Open Access. This article is distributed under the terms of the Creative Commons Attribution-NonCommercial 4.0 International License (http://creativecommons.org/licenses/ by-nc/4.0/), which permits any noncommercial use, distribution, and reproduction in any medium, provided you give appropriate credit to the original author(s) and the source, provide a link to the Creative Commons license, and indicate if changes were made.

\section{REFERENCES}

1. Kerwin BA. Polysorbates 20 and 80 used in the formulation of protein biotherapeutics: structure and degradation pathways. J Pharm Sci. 2008;97(8):2924-35.

2. Khan TA, Mahler HC, Kishore RS. Key interactions of surfactants in therapeutic protein formulations: a review. Eur J Pharm Biopharm. 2015;97(Pt A):60-7.

3. ten Tije AJ, Verweij J, Loos WJ, Sparreboom A. Pharmacological effects of formulation vehicles: implications for cancer chemotherapy. Clin Pharmacokinet. 2003;42(7):665-85.

4. Kaur G, Mehta SK. Developments of Polysorbate (Tween) based microemulsions: preclinical drug delivery, toxicity and antimicrobial applications. Int J Pharm. 2017;529(1-2):134-60.

5. Souney PF, Cooper WD, Cushing DJ. PM101: intravenous amiodarone formulation changes can improve medication safety. Expert Opin Drug Saf. 2010;9(2):319-33.

6. Hey E. Vitamin K-what, why, and when. Arch Dis Child Fetal Neonatal Ed. 2003;88(2):F80-3.

7. Taxotere $^{\circledR}$ (docetaxel) injection concentrate, intravenous infusion (IV) [prescribing information]. Bridgewater, NJ: Sanofi-Aventis; 2015.

8. Vaccine excipient and media summary. Centers for Disease Control and Prevention. https://www.cdc. gov/vaccines. Accessed Apr 112017.

9. Eprex $^{\circledR}$ (epoetin alfa) solution for injection in prefilled syringes [summary of product characteristics]. United Kingdom: Janssen-Cilag Ltd; 2017.
10. Aranesp $^{\circledR}$ (darbepoetin alfa) injection, for intravenous or subcutaneous use [prescribing information]. Thousand Oaks, CA: Amgen Inc; 2018.

11. Emend $^{\circledR}$ (fosaprepitant dimeglumine) for injection [prescribing information]. Whitehouse Station, NJ: Merck, Sharp \& Dohme; 2018.

12. van Zuylen L, Verweij J, Sparreboom A. Role of formulation vehicles in taxane pharmacology. Invest New Drugs. 2001;19(2):125-41.

13. Weiszhar Z, Czucz J, Revesz C, Rosivall L, Szebeni J, Rozsnyay Z. Complement activation by polyethoxylated pharmaceutical surfactants: cremophor-EL, Tween-80 and Tween-20. Eur J Pharm Sci. 2012;45(4):492-8.

14. Yang R, Lao QC, Yu HP, et al. Tween-80 and impurity induce anaphylactoid reaction in zebrafish. J Appl Toxicol. 2015;35(3):295-301.

15. Schellekens H. Factors influencing the immunogenicity of therapeutic proteins. Nephrol Dial Transplant. 2005;20(suppl 6):vi3-9.

16. Donbrow M, Azaz E, Pillersdorf A. Autoxidation of polysorbates. J Pharm Sci. 1978;67(12):1676-81.

17. van Tellingen $\mathrm{O}$, Beijnen JH, Verweij J, Scherrenburg EJ, Nooijen WJ, Sparreboom A. Rapid esterasesensitive breakdown of polysorbate 80 and its impact on the plasma pharmacokinetics of docetaxel and metabolites in mice. Clin Cancer Res. 1999;5(10):2918-24.

18. Sparreboom A, Zhao M, Brahmer JR, Verweij J, Baker SD. Determination of the docetaxel vehicle, polysorbate 80 , in patient samples by liquid chromatography-tandem mass spectrometry. J Chromatogr B Analyt Technol Biomed Life Sci. 2002;773(2):183-90.

19. Webster LK, Linsenmeyer ME, Rischin D, Urch ME, Woodcock DM, Millward MJ. Plasma concentrations of polysorbate 80 measured in patients following administration of docetaxel or etoposide. Cancer Chemother Pharmacol. 1997;39(6):557-60.

20. Harrison SD Jr, Cusic AM, McAfee SM. Tween 80 increases plasma Adriamycin concentrations in mice by an apparent reduction of plasma volume. Eur J Cancer. 1981;17(4):387-9.

21. Azmin MN, Stuart JF, Florence AT. The distribution and elimination of methotrexate in mouse blood and brain after concurrent administration of polysorbate 80. Cancer Chemother Pharmacol. $1985 ; 14(3): 238-42$.

22. Ellis AG, Crinis NA, Webster LK. Inhibition of etoposide elimination in the isolated perfused rat liver 
by Cremophor EL and Tween 80. Cancer Chemother Pharmacol. 1996;38(1):81-7.

23. Cummings J, Forrest GJ, Cunningham D, Gilchrist NL, Soukop M. Influence of polysorbate 80 (Tween 80) and etoposide (VP-16-213) on the pharmacokinetics and urinary excretion of Adriamycin and its metabolites in cancer patients. Cancer Chemother Pharmacol. 1986;17(1):80-4.

24. Wang Y, Wang C, Gong C, et al. Polysorbate 80 coated poly (varepsilon-caprolactone)-poly (ethylene glycol)-poly (varepsilon-caprolactone) micelles for paclitaxel delivery. Int J Pharm. 2012;434(1-2):1-8.

25. Loos WJ, Baker SD, Verweij J, Boonstra JG, Sparreboom A. Clinical pharmacokinetics of unbound docetaxel: role of polysorbate 80 and serum proteins. Clin Pharmacol Ther. 2003;74(4):364-71.

26. Anderberg EK, Nystrom C, Artursson P. Epithelial transport of drugs in cell culture. VII: effects of pharmaceutical surfactant excipients and bile acids on transepithelial permeability in monolayers of human intestinal epithelial (Caco-2) cells. J Pharm Sci. 1992;81(9):879-87.

27. Riehm H, Biedler JL. Potentiation of drug effect by Tween 80 in Chinese hamster cells resistant to actinomycin D and daunomycin. Cancer Res. 1972;32(6):1195-200.

28. Tatsuishi T, Oyama Y, Iwase K, et al. Polysorbate 80 increases the susceptibility to oxidative stress in rat thymocytes. Toxicology. 2005;207(1):7-14.

29. Kay ER. Effects of Tween 80 on the growth of the Ehrlich-Lettre ascites carcinoma. Experientia. 1965;21(11):644-5.

30. Kubis A, Witek R, Olszewski Z, Krupa S. The cytotoxic effect of Tween 80 on Ehrlich ascites cancer cells in mice. Pharmazie. 1979;34(11):745-6.

31. Witek R, Krupa S, Kubis A. Cytotoxic action of diethanolamine oleate on Ehrlich exudative carcinoma in mice, compared with the action of polyoxyethylene sorbitan mono-oleate (Tween 80). Arch Immunol Ther Exp (Warsz). 1979;27(3):321-4.

32. Chajes V, Sattler W, Stranzl A, Kostner GM. Influence of n-3 fatty acids on the growth of human breast cancer cells in vitro: relationship to peroxides and vitamin-E. Breast Cancer Res Treat. 1995;34(3):199-212.

33. Gough WB, Zeiler RH, Barreca P, El-Sherif $\mathrm{N}$. Hypotensive action of commercial intravenous amiodarone and polysorbate 80 in dogs. J Cardiovasc Pharmacol. 1982;4(3):375-80.
34. Roberts CL, Rushworth SL, Richman E, Rhodes JM. Hypothesis: increased consumption of emulsifiers as an explanation for the rising incidence of Crohn's disease. J Crohns Colitis. 2013;7(4):338-41.

35. Bergh M, Magnusson K, Nilsson JL, Karlberg AT. Contact allergenic activity of Tween 80 before and after air exposure. Contact Dermatitis. 1997;37(1):9-18.

36. Coors EA, Seybold H, Merk HF, Mahler V. Polysorbate 80 in medical products and nonimmunologic anaphylactoid reactions. Ann Allergy Asthma Immunol. 2005;95(6):593-9.

37. Steele RH, Limaye S, Cleland B, Chow J, Suranyi MG. Hypersensitivity reactions to the polysorbate contained in recombinant erythropoietin and darbepoietin. Nephrology (Carlton). 2005;10(3):317-20.

38. Rhodes A, Eastwood JB, Smith SA. Early acute hepatitis with parenteral amiodarone: a toxic effect of the vehicle? Gut. 1993;34(4):565-6.

39. Curran BJ, Havill JH. Hepatic and renal failure associated with amiodarone infusion in a patient with hereditary fructose intolerance. Crit Care Resusc. 2002;4(2):112-5.

40. Bove KE, Kosmetatos N, Wedig KE, et al. Vasculopathic hepatotoxicity associated with E-Ferol syndrome in low-birth-weight infants. JAMA. 1985;254(17):2422-30.

41. Dumontet C, Jordan MA. Microtubule-binding agents: a dynamic field of cancer therapeutics. Nat Rev Drug Discov. 2010;9(10):790-803.

42. Jibodh RA, Lagas JS, Nuijen B, Beijnen JH, Schellens $\mathrm{JH}$. Taxanes: old drugs, new oral formulations. Eur J Pharmacol. 2013;717(1-3):40-6.

43. Kadoyama K, Kuwahara A, Yamamori M, Brown JB, Sakaeda T, Okuno Y. Hypersensitivity reactions to anticancer agents: data mining of the public version of the FDA adverse event reporting system, AERS. J Exp Clin Cancer Res. 2011;30:93.

44. Francis PA, Rigas JR, Kris MG, et al. Phase II trial of docetaxel in patients with stage III and IV nonsmall-cell lung cancer. J Clin Oncol. 1994;12(6):1232-7.

45. Norris LB, Qureshi ZP, Bookstaver PB, et al. Polysorbate 80 hypersensitivity reactions: a renewed call to action. Community Oncol. 2010;7(9):425-8.

46. Lorenz W, Reimann HJ, Schmal A, et al. Histamine release in dogs by Cremophor E1 and its derivatives: 
oxethylated oleic acid is the most effective constituent. Agents Actions. 1977;7(1):63-7.

47. Zeng X, Tao W, Mei L, Feng S-S. Docetaxel-loaded nanoparticles of dendrimer-like amphiphilic copolymer for cancer therapy. J Control Release. 2015;213:e119.

48. ACTRN12614000171617: a phase 1 study of dendrimer-docetaxel (DEP ${ }^{\mathrm{TM}}$ docetaxel) in patients with advanced cancer. Australia New Zealand Clinical Trial Registry. https://www.anzctr.org.au. Accessed Nov 132017.

49. McKeage K. Nanosomal docetaxel lipid suspension: a guide to its use in cancer. Clin Drug Investig. 2017;37(4):405-10.

50. Ahmad A, Sheikh S, Taran R, et al. Therapeutic efficacy of a novel nanosomal docetaxel lipid suspension compared with taxotere in locally advanced or metastatic breast cancer patients. Clin Breast Cancer. 2014;14(3):177-81.

51. Rossert J, Casadevall N, Eckardt KU. Anti-erythropoietin antibodies and pure red cell aplasia. J Am Soc Nephrol. 2004;15(2):398-406.

52. Rizzo JD, Brouwers M, Hurley P, et al. American Society of Hematology/American Society of Clinical Oncology clinical practice guideline update on the use of epoetin and darbepoetin in adult patients with cancer. Blood. 2010;116(20):4045-59.

53. Emend $^{\circledR}$ (aprepitant) capsules, for oral use [prescribing information]. Whitehouse Station, NJ: Merck, Sharp \& Dohme; 2017.

54. Curran MP, Robinson DM. Aprepitant: a review of its use in the prevention of nausea and vomiting. Drugs. 2009;69(13):1853-78.

55. Aapro M, Carides A, Rapoport BL, Schmoll HJ, Zhang L, Warr D. Aprepitant and fosaprepitant: a 10 -year review of efficacy and safety. Oncologist. $2015 ; 20(4): 450-8$.

56. Rojas C, Raje M, Tsukamoto T, Slusher BS. Molecular mechanisms of 5-HT(3) and $\mathrm{NK}(1)$ receptor antagonists in prevention of emesis. Eur J Pharmacol. 2014;722:26-37.

57. Grunberg S, Chua D, Maru A, et al. Single-dose fosaprepitant for the prevention of chemotherapyinduced nausea and vomiting associated with cisplatin therapy: randomized, double-blind study protocol-EASE. J Clin Oncol. 2011;29(11):1495-501.

58. Saito H, Yoshizawa H, Yoshimori K, et al. Efficacy and safety of single-dose fosaprepitant in the prevention of chemotherapy-induced nausea and vomiting in patients receiving high-dose cisplatin: a multicentre, randomised, double-blind, placebocontrolled phase 3 trial. Ann Oncol. 2013;24(4):1067-73.

59. Weinstein C, Jordan K, Green SA, et al. Single-dose fosaprepitant for the prevention of chemotherapyinduced nausea and vomiting associated with moderately emetogenic chemotherapy: results of a randomized, double-blind phase III trial. Ann Oncol. 2016;27(1):172-8.

60. Hegerova LT, Leal AD, Grendahl DC, et al. An analysis of fosaprepitant-induced venous toxicity in patients receiving highly emetogenic chemotherapy. Support Care Cancer. 2015;23(1):55-9.

61. Tsuda T, Kyomori C, Mizukami T, et al. Infusion site adverse events in breast cancer patients receiving highly emetic chemotherapy with prophylactic anti-emetic treatment with aprepitant and fosaprepitant: a retrospective comparison. Mol Clin Oncol. 2016;4(4):603-6.

62. Leal AD, Kadakia KC, Looker S, et al. Fosaprepitantinduced phlebitis: a focus on patients receiving doxorubicin/cyclophosphamide therapy. Support Care Cancer. 2014;22(5):1313-7.

63. Sato Y, Kondo M, Inagaki A, et al. Highly frequent and enhanced injection site reaction induced by peripheral venous injection of fosaprepitant in anthracycline-treated patients. J Cancer. 2014;5(5):390-7.

64. Fujii T, Nishimura N, Urayama KY, et al. Differential impact of fosaprepitant on infusion site adverse events between cisplatin- and anthracycline-based chemotherapy regimens. Anticancer Res. 2015;35(1):379-83.

65. Boccia R, Geller R, Clendeninn N, Ottoboni T. A retrospective chart review of hypersensitivity and infusion-site adverse events (ISAEs) associated with fosaprepitant IV in patients receiving anthracycline and cyclophosphamide (AC)-based chemotherapy. Support Care Cancer. 2017;25(suppl 2):S21-S266: eP003.

66. Chow AY, Chin C, Dahl G, Rosenthal DN. Anthracyclines cause endothelial injury in pediatric cancer patients: a pilot study. J Clin Oncol. 2006;24(6):925-8.

67. Lundberg JD, Crawford BS, Phillips G, Berger MJ, Wesolowski R. Incidence of infusion-site reactions associated with peripheral intravenous administration of fosaprepitant. Support Care Cancer. 2014;22(6):1461-6.

68. Cinvanti ${ }^{\mathrm{TM}}$ (aprepitant) injectable emulsion, for intravenous use [prescribing information]. San Diego, CA, USA; Heron Therapeutics; 2017 Nov. 
69. Ottoboni T, Boccia G, Manhard K, et al. Bioequivalence and safety of HTX-019 (surfactant-free aprepitant IV) and fosaprepitant in healthy subjects. Support Care Cancer. 2017;25(suppl 2):S21-S266: PS056.

70. Wu G, Powers D, Yeung S, Chen F. Compatibility and stability of rolapitant injectable emulsion admixed with intravenous palonosetron hydrochloride injection and dexamethasone sodium phosphate injection. Int J Pharm Compd. 2018;22(1):76-85.

71. Wu G, Yeung S, Chen F. Compatibility and stability of rolapitant injectable emulsion admixed with dexamethasone sodium phosphate. Int J Pharm Compd. 2017;21(1):66-75.
72. $\operatorname{Varubi}^{\circledR}$ (rolapitant) injectable emulsion, for intravenous use [prescribing information]. Waltham, MA: Tesaro, Inc; 2018.

73. US Food and Drug Administration. Varubi (rolapitant) injectable emulsion: health care provider letter-anaphylaxis and other serious hypersensitivity reactions. https://www.fda.gov/Safety/MedWatch/ SafetyInformation/SafetyAlertsforHumanMedical Products/ucm592592.htm (2018). Accessed Jan 292018.

74. Tesaro announces fourth-quarter and full-year 2017 operating results. Tesaro news releases. http://ir. tesarobio.com/news-releases/news-release-details/ tesaro-announces-fourth-quarter-and-full-year-2017operating (2018). Accessed Mar 52018. 